\title{
PENGGUNAAN TOKSIN BOTULINUM-A DENGAN PANDUAN ULTRASONOGRAFI SEBAGAI TERAPI SINDROM PIRIFORMIS REKUREN: SERIAL KASUS
}

\author{
ULTRASOUND GUIDED BOTULINUM TOXIN-A INJECTION FOR RECURRENT \\ PIRIFORMIS SYNDROME: CASE SERIES
}

Yusak Mangara Tua Siahaan*

\begin{abstract}
Piriformis syndrome(PS) is a clinical syndrome with complaints of buttock pain that radiates to the unilateral side leg caused by sciatic nerve entrapment of piriformis muscle. Several therapy modalities of PS are oral, physical, intervention, and surgical therapy. Intramuscular injection therapy is an intervention therapy for patients who experience severe pain or have failed oral therapy and/or physical therapy. It generally involves the use of local anesthetics, corticosteroids or the botulinum toxin A. This study represents five cases of short-period recurrent PS in 4 females and 1 male with age variations from 32 to 43 years-old. All cases complained classic symptoms with sub-acute to chronic onset and previously had a conservative-interventional therapy. Long-term improvement ( $>9$ months) was experienced after intramuscular botulinumtoxin-A injection with ultrasound-guided.
\end{abstract}

Keywords: Botulinum toxin, injection therapy, piriformis syndrome.

\section{ABSTRAK}

Sindrom piriformis (SP) merupakan sindrom klinis dengan keluhan nyeri pantat menjalar ke tungkai sisi unilateral yang disebabkan penekanan saraf skiatik oleh otot piriformis. Beberapa modalitas terapi SP antaralain terapi oral, fisik, intervensi hingga pembedahan. Terapi injeksi intramuskular merupakan terapi intervensi bagi pasien yang mengalami nyeri hebat atau mengalami kegagalan terapi oral dan/atau terapi fisik. Terapi injeksi intramuskular umumnya berupa penggunaan anestesi lokal, kortikosteroid maupun toksin Botulinum A. Studi ini mewakili lima kasus SP yang mengalami kekambuhan dalam periode singkat pada 4 perempuan dan 1 laki-laki dengan variasi usia 32-43 tahun. Keseluruhan kasus mengeluhkan gejala klasik dengan onset subakut-kronik juga riwayat pengobatan konservatif dan intervensi. Perbaikan jangka panjang ( $>9$ bulan) dialami pascainjeksi toksin-botulinum-A dengan panduan ultrasonografi.

Kata Kunci: Sindrom piriformis, terapi injeksi, toksin botulinum

*Departemen Neurologi Fakultas Kedokteran Universitas Pelita Harapan/SMF Neurologi RS Siloam Karawaci. Korespondensi: dryusaks2002@gmail.com

\section{PENDAHULUAN}

Sindrom piriformis (SP) merupakan salah satu penyebab nyeri punggung bawah dengan prevalensi berkisar $12,2-27 \%$. Secara epidemiologi, SP umumnya didapati pada usia dekade 4 sampai 5 , dengan rasio perempuan dibandingkan laki-laki sebesar 6:1. ${ }^{1}$ Hingga saat ini, prevalensi SP sulit ditentukan karena sindrom ini masih sering salah didiagnosis dengan penyebab NPB lainnya. Salah satu studi observasi di Indonesia, mencatat sebanyak 3,2\% (6 dari 152) pasien dengan SP berkunjung ke poli fisioterapi RS Moch Ansari, Banjarmasin pada tahun 2017-2018. ${ }^{2}$

Sindrom piriformis didefinisikan sebagai sindrom klinis dengan keluhan nyeri bokong menjalar ke kaki sisi unilateral yang disebabkan penekanan saraf skiatik oleh otot piriformis. ${ }^{1,3-4}$
Nyeri yang mendasari SP meliputi komponen nyeri somatik, neuropatik, atau keduanya. Nyeri somatik disebabkan oleh nyeri miofasial dari otot piriformis, sedangkan nyeri neuropatik berasal dari saraf skiatik yang terjepit akibat inflamasi dan hipertrofi otot piriformis. Jika proses ini berlangsung terus-menerus, maka akan terjadi peningkatan sensitisasi sentral dan aktivasi dari jalur nyeri neuropatik. ${ }^{5}$

Salah satu alternatif terapi yang banyak digunakan praktisi saat ini adalah terapi injeksi intramuskular. Terapi injeksi intramuskular umumnya berupa penggunaan anestetik lokal, kortikosteroid, dan toksin Botulinum A (Botox/BTX-A)., ${ }^{4,6}$

Dibandingkan dengan anestetik lokal dan kortikosteroid, penggunaan BTX-A pada praktik sehari-hari masih sangat minim karena harganya yang mahal dan ketersediaannya yang jarang. Oleh 
karena itu, studi ini membahas lima kasus SP yang diberikan BTX-A dan mengalami efek perbaikan jangka panjang.

\section{KASUS}

Lima pasien dengan variasi usia 32 hingga 43 tahun yang terdiri dari 4 perempuan dan 1 lakilaki datang dengan keluhan nyeri pantat unilateral yang konstan disertai penjalaran pada tungkai. Tiga penderita mengalami perburukan nyeri jika dilakukan perubahan posisi tertentu, sedangkan yang lainnya tidak. Kelimanya memiliki skala nyeri diatas 8/10, tanpa disertai baal, kelemahan satu sisi, riwayat makrotrauma maupun tumor sebelumnya. Pemeriksaan klinis ditemukan trigger point piriformis positif dan minimal 2 uji provokatif berupa flexion adduction internal rotation (FAIR), Freiberg, Pace, dan Beatty positif. Elektrodiagnostik dilakukan untuk menyingkirkan adanya radikulopati lumbal atau pleksopati. Pada seorang pasien, pemeriksaan magnetic resonance imaging (MRI) panggul menunjukkan atrofi otot piriformis dengan struktur normal pada saraf skiatik, sedangkan yang lainnya tidak dilakukan (Tabel 1).

Keseluruhan pasien dilakukan blok diagnostik dengan kombinasi anestetik lokal dan kortikosteroid dipandu ultrasonografi (USG) dan menghasilkan pengurangan skala nyeri signifikan menjadi 2-3/10. Namun demikian, semua pasien mengalami kekambuhan nyeri intensitas berat (NRS 8-10/10) pada sisi yang sama kurang dari seminggu pascainjeksi. Selanjutnya, dengan persetujuan pasien, dilakukan pemberian injeksi 100U BTX-A intramuskular otot piriformis dengan panduan USG dan didapatkan penurunan skala nyeri yang besar (Tabel 2). Sebelum injeksi dilakukan, pasien dianamnesis dan diberikan edukasi mengenai reaksi alergi, serta kemungkinan efek samping berupa kelemahan otot. ${ }^{9,10}$ Prosedur intervensi diawali dengan prosedur antisepsis dan injeksi dilakukan secara perlahan dengan visualisasi otot piriformis dan penempatan jarum yang tepat untuk menghindari hematoma dan injeksi yang tidak sesuai target.

Evaluasi berkala pada kelima pasien menunjukkan bahwa nyeri masih tidak dirasakan bervariasi selama $9,12,15$, dan 18 bulan pascainjeksi. Sepanjang observasi, tidak didapatkan efek samping berupa hematoma, infeksi pascainjeksi, dan kelemahan otot piriformis (Tabel 2).

\section{PEMBAHASAN}

Studi kasus ini mewakili 5 kasus SP klasik dengan intensitas nyeri berat yang mengalami kekambuhan dalam waktu singkat pascainjeksi kombinasi anestetik lokal dan kortikosteroid. Sejalan dengan beberapa studi terkait SP, BTX-A dapat dipertimbangkan sebagai terapi alternatif jangka panjang apabila terdapat kegagalan terhadap terapi lain. ${ }^{3,7-8,5,11}$ Selain harga dan kesediaan obat yang tidak mudah didapatkan pada seluruh fasilitas kesehatan, awitan terjadinya SP turut menjadi pertimbangan. Efektivitas BTX-A dinilai lebih baik dalam menangani kasus nyeri kronik menurut studi Kumar dan Park. ${ }^{11,12}$

Keseluruhan kasus datang dengan manifestasi nyeri bokong unilateral dengan penjalaran pada tungkai bawah dan diperberat dengan perubahan posisi tertentu. Diagnosis SP pada kelima kasus ditegakkan melalui manifestasi klinis, pemeriksaan fisik dan blok diagnostik. Tindakan blok diagnostik penting dilakukan untuk mendukung penegakan diagnosis SP dan menyingkirkan diagnosis banding, antara lain hernia nukelus pulposus (HNP) lumbal, spasme otot gluteus, serta gangguan sendi faset dan sakroiliaka. ${ }^{6}$

Beberapa modalitas yang umumnya digunakan dalam tatalaksana SP berupa terapi oral (obat anti inflamasi nonsteroid (OAINS), relaksan, analgesik adjuvan), terapi fisik atau fisioterapi, terapi injeksi intramuskular, hingga terapi pembedahan. Keseluruhan modalitas tidak selalu dilakukan secara berurutan, tetapi bergantung pada kondisi yang dihadapi pasien seperti intensitas nyeri berat, dampak sosial dan pekerjaan yang terganggu, ataupun penolakan pasien terhadap modalitas terapi tertentu. ${ }^{7,13}$

Dalam lingkup pengetahuan penulis, hingga saat ini belum ada penelitian yang menunjukkan efektivitas suatu modalitas terapi yang lebih superior dibandingkan dengan terapi lainnya. Hal ini mengakibatkan pemilihan terapi seringkali bergantung pada pengalaman klinisi dalam mengobati pasien SP. 







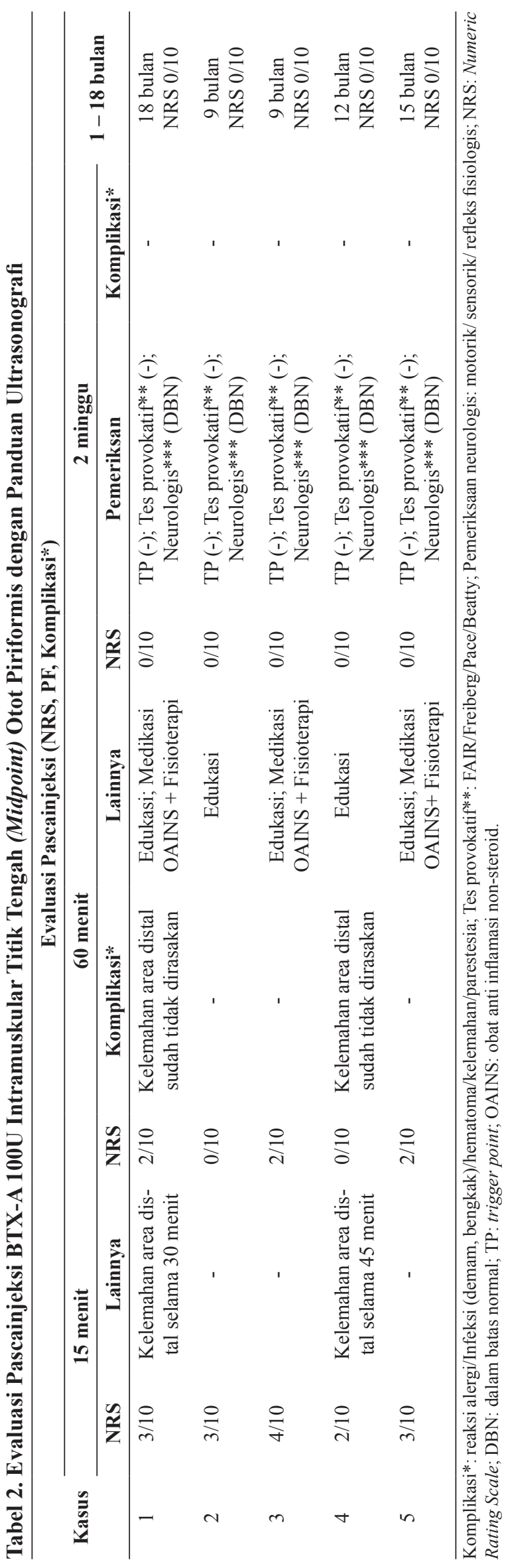

Injeksi intramuskular merupakan alternatif terapi yang paling sering digunakan dalam praktek sehari-hari terutama pada kasus dengan intensitas nyeri yang hebat dan mengganggu aktivitas penderita. Kelebihan injeksi intramuskular ialah efektivitas reaksi obat dalam menurunkan derajat nyeri secara cepat. Terapi kombinasi anestetik lokal dan kortikosteroid terbukti efektif dalam menurunkan skala nyeri dengan segera, tetapi belum banyak studi mengenai keberhasilan terapi ini dalam jangka waktu panjang. ${ }^{14-15}$

Pada kelima kasus diatas, terjadi kekambuhan kurang dari seminggu pascainjeksi dengan intensitas nyeri berat. Repetisi injeksi kombinasi lokal anestetik dan kortikosteroid dalam kurun waktu singkat tidak disarankan karena meningkatkan insidensi komplikasi dan efek samping seperti depigmentasi kulit, empisiema sendi, serta toksisitas sistemik yang dapat mengakibatkan disabilitas hingga kematian. ${ }^{16}$

Selain anestetik lokal dan kortikosteroid, BTX-A merupakan alternatif lain dalam terapi injeksi intramuskular SP. Pada umumnya, BTX-A digunakan sebagai terapi baku standar pada kasus hipertonia fokal atau distonia yang berperan dalam memblok pelepasan asetilkolin pada taut neuromuskular otot, sehingga menurunkan spastisitas., ${ }^{9}, 12,14$

Studi lain mendeskripsikan penggunaan BTX-A pada kasus nyeri miofasial dan kondisi nyeri kronik berat seperti nyeri kepala, artritis, dan nyeri neuropatik. Sayangnya, masih sedikit laporan yang menyebutkan aplikasinya pada SP secara spesifik. ${ }^{14}$ Terdapat dua mekanisme utama BTX-A dalam manajemen nyeri. Secara langsung, toksin ini menghilangkan aktivitas kontraksi otot melalui sensitisasi nosiseptor yang menurunkan $\mathrm{pH}$. Secara tidak langsung, BTX-A mencegah pelepasan neurotransmiter seperti substansi $\mathrm{P}$, cancitonin generelated peptide (CGRP), somatostatin, serotonin, adenosine triphosphate (ATP), dan bradikinin yang berperan dalam sensitisasi dan stimulasi nosiseptor otot. Dengan demikian, terjadi hambatan sinyal nyeri menuju dan dari sistem saraf pusat. ${ }^{11,14}$

Karakteristik neurotoksik dari BTX-A merupakan katalis kuat yang berperan dalam 
mengurangi kompresi saraf skiatik dengan cara merelaksasi atau melakukan paralisis otot piriformis. ${ }^{14}$ Kemampuannya dalam menghambat sinaptik eksositosis akan memotong transmisi neural. ${ }^{17}$ Dengan dosis yang sesuai, denervasi parsial akan menginduksi penurunan kontraksi otot tanpa paralisis total. Toksin ini dinilai berperan khusus di muscle spindle dengan menghambat neuron motorik gamma dan memblokir sinyal aferen tipe Ia yang mempengaruhi jalur sensorik dan motorik. ${ }^{14}$ Secara umum, paralisis otot akibat toksin ini timbul dalam waktu 2-5 hari pascainjeksi dan dapat bertahan selama 6 minggu hingga 6 bulan (median 3-4 bulan), tergantung dosis yang diberikan. ${ }^{14,18}$ Hal inilah yang mungkin mendasari efek jangka panjang dari penggunaan BTX-A pada SP.

Studi terdahulu menggunakan beberapa modalitas seperti EMG, fluoroskopi, USG, CT-scan, dan MRI pada injeksi SP untuk mengonfirmasi keberadaan ujung jarum pada posisi intramuskular terdekat dengan saraf skiatika. Ketepatan lokasi tersebut turut mempengaruhi efektivitas maksimal terapi.

Panduan EMG sulit mengonfirmasi lapisan intramuskular dengan akurat. Selain itu, fluoroskopi, CT scan, dan MRI dinilai tidak efisien karena memerlukan fasilitas memadai, biaya yang lebih besar, dan waktu yang lebih lama. Dalam studi Zhang dkk yang membandingkan penggunaan MRI dan USG dalam mendiagnosis SP, didapatkan hasil yang tidak berbeda jauh. ${ }^{19}$ Oleh karena itu, penggunaan USG dinilai superior dalam mengidentifikasi otot piriformis (Gambar 1) serta efisien waktu dan biaya dibandingkan dengan modalitas lainnya. ${ }^{6}$

\section{KESIMPULAN}

Injeksi BTX-A dapat menjadi pertimbangan terapi jangka panjang pada penderita SP yang mengalami rekurensi atau kegagalan terapi konvensional lainnya.

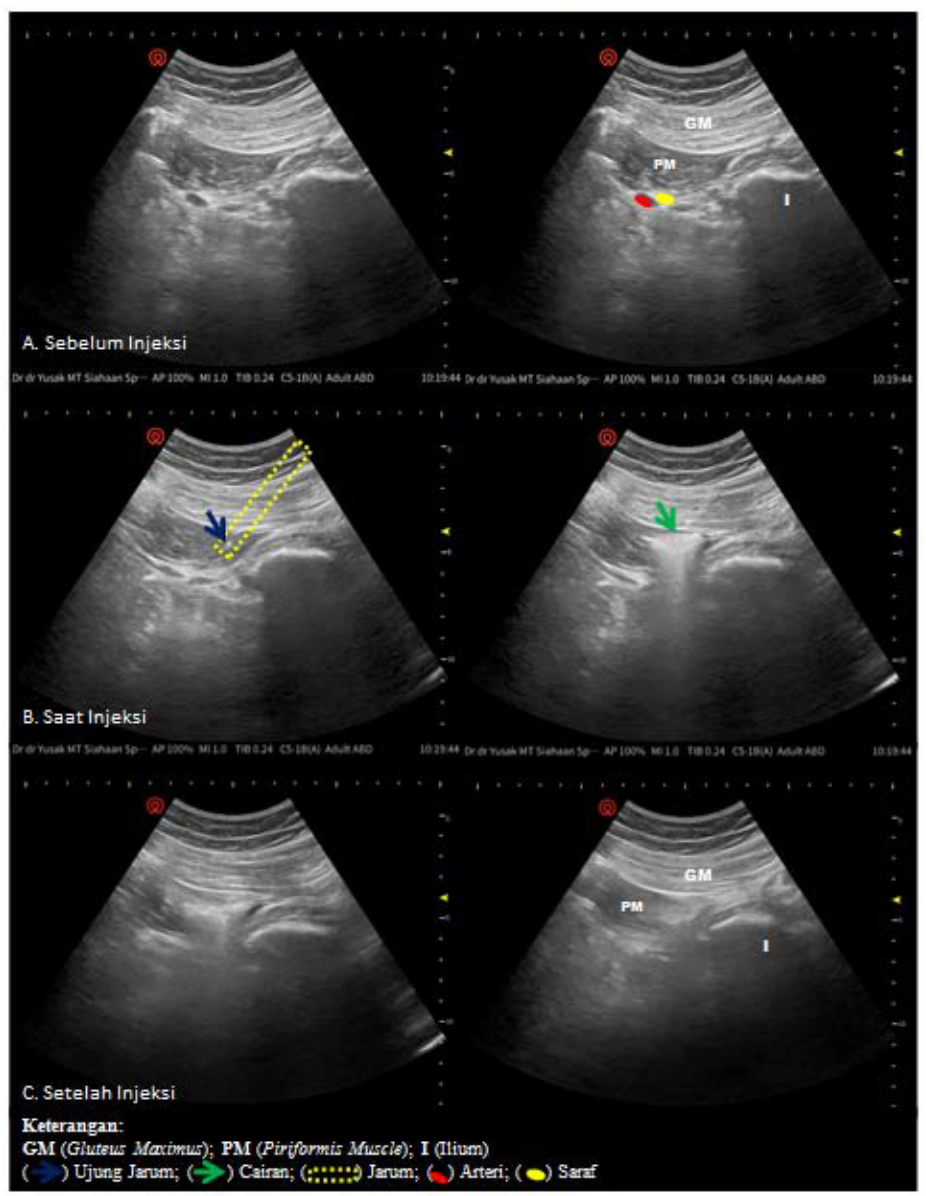

Gambar 1. Injeksim piriformis dengan panduan ultrasonografi 


\section{DAFTAR PUSTAKA}

1. Siahaan YMT, Ketaren RJ, Hartoyo V, Tiffani P. The Predisposing Factors of Piriformis Syndrome: Study in a Referral Hospital. MNJ. 2019; 5(2): 76-9.

2. Puteri AR, Nafi'ah, Tahdi M. Penatalaksanaan Fisioterapi pada Penderita Gangguan Nyeri akibat Sindrom Piriformis dengan Teknik Strain Counterstrain dan Contract Relax Stretching di Kelurahan Pekapuran Raya Kota Banjarmasin. JKiKT. 2019; 1(2): 8-14.

3. Ripellino P, Cianfoni A, Izzo MGA, Gobbi C. Relapsing piriformis syndrome treated with botulinum injections. BMJ Case Rep. 2019; 12:e230981.

4. Siddiq AB, Rasker JJ. Piriformis syndrome: still unsolved issues. Int J Clin Rheumatol. 2018; 13(6):338-40.

5. Terlemez R, Ercalik T. Effect of piriformis injection on neuropathic pain. Agri. 2019; 31(4): 178-82

6. Bhatia A, Peng P. Pelvic muscles. Dalam Peng P, Finlayson R, Lee SH, Bhatia A, editor. Ultrasound for Interventional Pain Management, Switzerland: Springer; 2020. h 93-106.

7. Rodriguez-Pinero. Long-Term Efficacy of Ultrasound-Guided Injection of IncobotulinumtoxinA in Piriformis Syndrome. Pain Med. 2018; 19:408-11.

8. Cordero-Garcia C, Garcia-Delgado MM. Efficacy of ultrasound-guided injections of incobotulinumtoxin A in the management of piriformis muscle syndrome. Ann. Phys. Rehabil. Med.2018; 61: e162.

9. Attal N, Bouhassira D. Pharmacotherapy of neuropathic pain: which drugs, which treatment algorithms? Pain. 2015; 156 (Suppl 1): S104-14.

10. Injection Technique for Piriformis Syndrome and Sciatic Nerve Block. Dalam: Waldman SD. Atlas of
Pain Management Injection Techniques. Missouri: Elsevier; 2017. h. 453-7.

11. Kumar R. Therapeutic use of botulinum toxin in pain management. NS. 2018;2: 1-18.

12. Park JH, Park HJ. Botulinum toxin for the treatment of neuropathic pain. Toxins. 2017; 9(260): 1-15.

13. Badowski EA, Byrd JWT. Piriformis injection: an ultrasound-guided technique. Arthrosc Tech. 2019; 8(12): e1457-61.

14. Santamato A, Micello MF, Ranieri M. UltrasoundGuided Injection of Botulinum Toxin Type A for Piriformis Muscle Syndrome: A Case Report and Review of the Literature. Toxins (Basel). 2015; 7(8):3045-56.

15. Misirlioglu TO, Akgun K, Palamar D, Erden MG, Erbilir T. Piriformis Syndrome: Comparison of the Effectiveness of Local Anesthetic and Corticosteroid Injections: A Double-Blinded, Randomized Controlled Study. Pain Physician. 2015; 18: 163-71.

16. Simurina T, Mraovic B, Zupcic M, Zupcic SG, Vulin M. Local Anesthetics and Steroids: Contraindications and Complications - Clinical Update. Acta Clin Croat. 2019; 58(1): 53-61.

17. Bouhassira D, Attal N. Emerging therapies for neuropathic pain: new molecules or new indications for old treatments? Pain. 2018; 159(3): 576-82.

18. Al-Al-Shaikh M, Michel F, Parratte B, Kastler B, Vidal C, Aubry S. An MRI Evaluation of changes in Piriformis Muscle morphology induced by botulinum toxin injections in the treatment of piriformis syndrome. Diagn Interv Imaging. 2015; 96(1):37-43.

19. Zhang W, Luo F, Sun H, Ding H. Ultrasound appears to be a reliable technique for the diagnosis of piriformis syndrome. Muscle Nerve. 2019; 59(4):411-6. 